\title{
Pembentukkan Pusat Informasi dan Konseling Kesehatan Reproduksi Remaja (PIK-KRR) di SMPN 28 Kota Pekanbaru
}

\author{
Yanti*1, Lailiyana $^{2}$ \\ 1,2Prodi DIV Kebidanan, Jurusan Kebidanan, Poltekkes Kemenkes Riau \\ *e-mail: yanti@pkr.ac.id
}

\begin{abstract}
Malnutrition in toddlers is still a health problem in Indonesia. Malnutrition generally occurs in children under age 5, because at this age, children experience rapid growth. It is estimated there are still around 1.7 million children under threat of malnutrition scattered throughout Indonesia. The purpose of this community service activity is to conduct training for cadres in maternal and child health service (posyandu) about the skills in giving MP-ASI counselling in Tanah Merah village, Siak Hulu Subdistrict, Kampar Regency in 2019. The method of this activity carried out disseminating information on community service activities in the village apparatus, providing material and the practice of counselling by cadres in maternal and child health service (Posyandu). The results of this community service activities were the socialization of community service activities to village officials, the Siak Hulu Health Center and Posyandu cadres in the village office hall, followed by the provision of material for four meetings. To assess the successful implementation of community service activities, a cadre practice was conducted on the Posyandu day. Based on the results of the pre and post-test evaluations, there was an increase in cadre knowledge about the MPASI material. It is recommended for Posyandu cadres to apply the results of the training by activating extension activities by cadres at table V every Posyandu opening day.
\end{abstract}

Keywords : PIK-KRR, adolescent reproductive health

\begin{abstract}
Abstrak
Kekurangan gizi pada Balita hingga kini masih menjadi masalah kesehatan Indonesia. Kekurangan gizi pada umumnya terjadi pada Balita karena pada umur tersebut, anak mengalami pertumbuhan yang pesat. Diperkirakan masih terdapat sekitar 1,7 juta balita terancam gizi buruk yang keberadaannya tersebar di pelosok-pelosok Indonesia. Tujuan dilakukannya kegiatan pengabdian kepada masyarakat ini adalah melakukan pelatihan pada kader posyandu tentang keterampilan memberikan penyuluhan MP-ASI di desa Tanah Merah Kecamatan Siak Hulu Kabupaten Kampar Tahun 2019. Metode kegiatan pengabdian masyarakat ini dilakukan dengan cara melakukan sosialisasi kegiatan pengabmas pada perangkat desa, pembekalan materi dan praktik penyuluhan oleh kader di Posyandu. Hasil kegiatan pengabdian kepada masyarakat ini adalah telah dilaksanakan kegiatan sosialisasi kegiatan pengabmas kepada perangkat desa, Puskesmas Siak Hulu dan kader Posyandu di aula kantor desa, dilanjutkan dengan pembekalan materi selama 4 kali pertemuan. Untuk menilai keberhasilan pelaksanaan kegiatan pengabmas, dilakukan praktik penyuluhan oleh kader di hari Posyandu. Berdasarkan hasil evaluasi pre dan post test terdapat peningkatan pengetahuan kader tentang materi MP-ASI. Disarankan kepada kader Posyandu dapat mengaplikasikan hasil pelatihan dengan mengaktifkan kegiatan penyuluhan oleh kader di meja V setiap hari buka Posyandu.
\end{abstract}

Kata kunci : PIK-KRR, Kesehatan reproduksi remaja

\section{PENDAHULUAN}

Masa remaja merupakan periode terjadinya pertumbuhan dan perkembangan yang pesat baik secara fisik, psikologis maupun intelektual. Berdasarkan data dari UNICEF (2016), jumlah populasi remaja usia 10-19 tahun saat ini sebanyak 1,2 milyar atau 16\% dari populasi dunia. Sedangkan populasi remaja usia 10-24 tahun di ASIA sebanyak 802 juta pada tahun 2013. Di Indonesia, menurut data proyeksi penduduk (2014), jumlah remaja mencapai sekitar 65 juta jiwa atau 25 persen dari 255 juta jiwa jumlah penduduk. Jumlah kelompok usia 10-19 tahun 
menurut Sensus Penduduk 2015 sebanyak 43,5 juta atau sekitar 18\% dari jumlah penduduk (BKKBN, 2017).

Data dari Kemenkes (2016), presentase remaja dalam melakukan seks pra nikah terus meningkat. Secara umum, remaja laki-laki lebih banyak yang menyatakan pernah melakukan seks pra nikah dibanding dengan remaja perempuan (Isa, 2017). Persentase pada tahun 2012 cenderung meningkat dibandingkan data tahun 2007. Alasan dilakukannya seks pra nikah adalah karena rasa penasaran atau ingin tahu Berdasarkan data dari The World's Youth (2013) banyak remaja usia 15-19 tahun telah memiliki anak, terutama di negara-negara berkembang dan mulai menikah di usia sebelum 18 tahun. Tingginya angka pernikahan pada usia muda dan banyaknya jumlah ibu hamil di bawah 20 tahun tidak dapat dipungkiri bahwa sebagian besar dikarenakan kehamilan pranikah (Isa, 2017).

Generasi muda merupakan generasi ujung tombak dalam suatu bangsa. Kualitas dan perilaku dari remaja disuatu bangsa akan menentukan arah kemajuan suatu bangsa. Namun, tidak dapat dipungkiri kenyataan bahwa di Indonesia, perilaku generasi muda sudah mencapai tahap yang memperihatinkan. Gaya hidup dan informasi serta berbagai faktor lainnya turut mempengaruhi pengetahuan, sikap dan perubahan perilaku kehidupan remaja yang kemudian berpengaruh pada perilaku kehidupan kesehatan reproduksi mereka. Segala yang mempengaruhi perilaku kesehatan reproduksi jika tidak segera ditangani dengan seksama akan berdampak pada kesehatan reproduksi remaja.

Disamping itu, program yang selama ini telah berjalan di sekolah menengah utamanya mengenai kesehatan reproduksi remaja belum mengarah pada hasil yang diharapkan. Kebanyakan dari program yang telah ada hanya fokus pada materi bukan pada kebersinambungan program untuk kedepannya. Hasilnya, program yang dibuat hanya berumur pendek. Program ini menawarkan sebuah metode, dimana pendidikan kesehatan reproduksi remaja dapat berkembang secara berkesinambungan dan menjadikan generasi muda sebagai pelopor Generasi Berencana (Gen-Re). Peran tim pengabdian masyarakat hanyalah sebagai fasilitator, untuk selanjutnya siswa yang akan menjadi kader kesehatan reproduksi sendiri yang akan aktif untuk menggemakan kesehatan reproduksi di lingkungan sekolah dan masyarakat sekitarnya. Menyikapi persoalan tersebut, pembentukan dan pemberdayaan kader kesehatan reproduksi sangat penting dilakukan di sekolah, terutama di SMPN 28 Tebing Tinggi Okura kota Pekanbaru.

Berdasarkan observasi, SMPN 28 Tebing Tinggi Okura belum memiliki Pusat Informasi dan Konseling Kesehatan Reproduksi Remaja (PIK-KRR) dengan pembentukkan dan pemberdayaan Tim Kader Kesehatan Reproduksi, diharapkan dapat meningkatkan Program PIK-KRR sekolah. Tak hanya itu, melalui pemberdayaan Tim Kader Reproduksi diharapkan dapat menjadi penggerak sekaligus promotor dalam peningkatan pengetahuan dan sikap bagi siswa lainnya serta mengurangi dampak pergaulan bebas di lingkungan sekolah. Tim Kader Reproduksi ini merupakan siswa/i yang memenuhi kriteria dan telah terlatih untuk ikut melaksanakan Program PIK-KRR di lingkungan sekolah. Secara umum target luaran yang akan dicapai dalam pengabdian ini adalah untuk membentuk dan memberdayakan Tim Kader Reproduksi di SMPN 28 Tebing Tinggi Okura kota Pekanbaru. Sehingga nantinya ini akan menjadi percontohan sebagai sekolah peduli masa depan bagi daerah lain.

\section{METODE}

Kegiatan pengabdian masyarakat ini dilaksanakan pada bulan April sampai Juli 2019, lokasi bertempat pada SMPN 28 Tebing Tinggi Okura Kota Pekanbaru. Metode kegiatan dengan cara melakukan sosialisasi tujuan dan manfaat kegiatan Pusat Informasi dan Konseling Kesehatan Reproduksi Remaja (PIK-KRR) kepada seluruh guru dan siswa SMPN 28 Tebing 
Tinggi Okura. Langkah berikutnya adalah pembentukkan PIK-KRR dengan melatih kader dari siswa-siswi yang terpilih yang merupakan perwakilan kelas 1 SMPN 28. Selanjutnya secara berkala dilakukan pembinaan terhadap PIK-KRR yang telah terbentuk untuk memantau pelaksanaan organisasi tersebut.

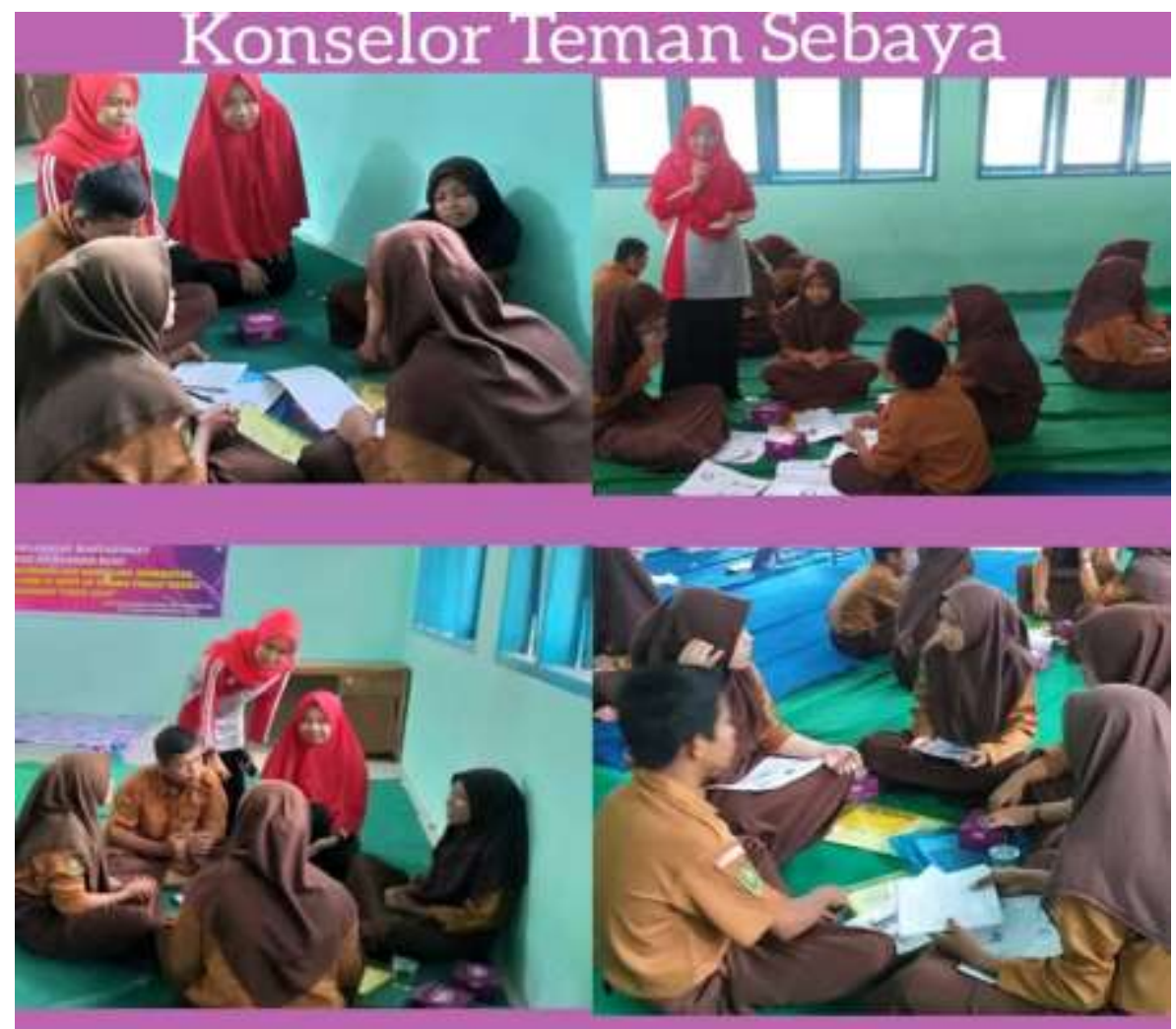

Gambar 1. Pembetukkan Konselor Teman Sebaya

\section{HASIL DAN PEMBAHASAN}

\subsection{Hasil}

SMPN 28 adalah salah satu sekolah menengah pertama negeri yang letaknya di jalan Raja Panjang kelurahan Tebing Tinggi Okura berada dipinggiran kota Pekanbaru. Jaraknya cukup jauh dari pusat kota sekitar $\pm 28 \mathrm{~km}$ dan $\pm 22 \mathrm{~km}$ dari Poltekkes Kemenkes Riau dengan jarak tempuh \pm 30 menit dengan kendaraan bermotor. Secara geografis lokasi SMPN 28 jauh dari pemukiman penduduk, sekitar sekolah di penuhi oleh kebun sawit. Sekolah didirikan oleh pemerintah kota Pekanbaru tahun 2002 dan langsung di operasikan menerima satu kelas yang dikepalai oleh Hasnida Nengleli, M.Pd. Saat ini sekolah telah berjalan selama 17 tahun dikelola oleh 9 orang guru sarjana S1, dengan jumlah siswa tahun 2018 yaitu 136 orang terdiri dari 5 kelas. Tahun 2019 terjadi penurunan jumlah siswa menjadi 96 orang terdiri dari 4 kelas, sedangkan daya tampung lebih dari 6 kelas . Sarana dan prasarana sekolah cukup memadai, kualifikasi guru pengajar sesuai dengan yang dipersyaratkan, sehingga SMPN 28 layak mendapat status akreditasi A dari Dinas Pendidikan.

Sekolah SMPN 28 berada jauh dari pusat kota, sasaran input siswa berasal dari kelurahan Tebing Tinggi Okura dan kelurahan Limbungan saja, sehingga jumlah siswa kurang dari target yang diharapkan. Hasil evaluasi 5 tahun terakhir terdapat beberapa siswa yang tidak menyelesaikan wajib belajar dengan kasus kenakalan remaja (mencuri, bolos sekolah) dan hamil diusia sekolah selanjutnya menikah. Daerah pinggiran kota menjadi lingkungan yang 
rawan terhadap pergaulan bebas, arus obat-obat terlarang, pencurian dan prilaku kenakalan remaja lainnya. Hal ini didukung oleh demografis wilayah yang berada disekitar kebun sawit, memungkinkan siswa mempunyai tempat berkumpul yang aman tanpa diketahui oleh masyarakat sekitarnya. Pentingnya pengawasan orang tua dan pengetahuan kehidupan remaja yang terencana di sekolah menjadi penapis bagi generasi muda terhadap hal-hal yang berkaitan dengan kenakalan remaja. Organisasi PIK-Remaja menjadi solusi sebagai wadah yang sehat perkumpulan remaja untuk mendiskusikan tentang masa depan dan kesehatan reproduksi yang terencana.

Pelaksanaan kegiatan pengabdian pada masyarakat tentang Pembentukkan Pusat Informasi dan Konseling Kesehatan Reproduksi Remaja Tahun 2019 di SMPN 28 Tebing Tinggi Okura Kota Pekanbaru telah dilaksanakan melalui 3 (tiga) tahapan. Tahapan yang dilakukan yaitu; 1.Sosialisasi kegiatan Pengabmas 2.Pembekalan materi 3.Praktik penyuluhan dan konseling oleh kader pada kelompok sebaya. Sosialisasi kegiatan pengabdian masyarakat pada seluruh siswa dan majelis guru SMPN 28, menyampaikan tujuan \& manfaat pembentukkan PIKKRR bagi sekolah. Tahap ke-2 pelaksanaan kegiatan pengabmas dalam bentuk pembekalan materi bagi peserta pelatihan, yang diberikan sebanyak 4 kali pertemuan di kelas. Penilaian peningkatan pengetahuan peserta perlu dilakukan melalui evaluasi pre dan post test, agar dapat mengetahui keberhasilan pembekalan materi yang diberikan. Selanjutnya adalah penerapan dalam bentuk praktik memberikan penyuluhan dan konseling oleh peserta pada kelompok teman sebaya di lingkungan SMPN 28.

Tim pengabmas juga bekerjasama lintas sektor dengan bagian Dir.Binmas Polda Riau dalam memberikan salah satu materi yaitu mengenai "Penyalahgunaan Napza". Tim meminta narasumber dari Polda Riau dengan pertimbangan bahwa materi tersebut lebih tepat langsung diberikan oleh pihak kepolisian Republik Indonesia. Permintaan untuk menjadi narasumber tamu pada kegiatan pengabmas yang kami kelola, mendapat sambutan baik dari Polda Riau. Hadirnya pihak kepolisian tim Dir.Binmas Polda Riau yang berjumlah 4 orang perwira Polisi di SMPN 28 menjadi warna baru dan mendapat sambutan istimewa dari pihak sekolah.

Peserta yang telah diberikan pelatihan dan pembinaan dipersiapkan untuk menjadi kader pengelola PIK-R dan konselor teman sebaya di sekolah. Kader PIK-R dikukuhkan secara simbolis pada acara pelantikkan oleh kepala sekolah yang berjumlah 18 orang perwakilan dari kelas VIII \& IX. Organisasi PIK-R yang telah dibentuk dan kader yang telah dikukuhkan telah dibuatkan Surat Keterangan (SK) tertulis yang ditandatangani oleh kepala sekolah. Pada SK yang telah diterbitkan oleh SMPN 28 mengenai pembentukkan PIK-Remaja tertulis PIK-R Action dengan pertimbangan organisasi ini akan memberikan layanan pada semua permasalahan remaja bukan hanya fokus terhadap kesehatan reproduksi remaja saja. PIK-R Action yang dibentuk didukung sepenuhnya oleh pihak SMPN 28, sekolah menyediakan ruangan PIK-R bersama dengan organisasi OSIS. Untuk melengkapi nyatanya identitas PIK-R Action SMPN 28, tim pengabmas memberikan bantuan berupa plang nama yang diserahkan simbolis kepada kepala sekolah pada acara penutupan. Bantuan plang nama yang diberikan, diperuntukkan untuk di pasang di depan ruangan PIK-R sebagai penunjuk identitas resmi organisasi. Untuk kegiatan rutin PIK-R dijadwalkan setiap hari Sabtu pada jam ekstra kurikuler. Hasil pelaksanaan kegiatan dapat dilihat pada tabel berikut ini :

Tabel 1. Perbandingan rata-rata nilai Pengetahuan Kader PIK-R berdasarkan Hasil Pretest dan Post test

\begin{tabular}{llcc}
\hline No & \multicolumn{1}{c}{ Pengetahuan tentang Materi PIK- } \\
Remaja & n & mean \\
\hline 1 & Pretest & 18 & 75 \\
2 & Post test & 18 & 96 \\
\hline
\end{tabular}


Pada tabel 1 dapat dilihat bahwa rata-rata nilai pengetahuan kader tentang materi pusat informasi dan konseling kesehatan reproduksi remaja, sebelum dan sesudah dilakukan pembekalan materi mengalami peningkatan yaitu dari rata-rata nilai 75 menjadi rata-rata 96. Nilai yang dihasilkan pada post test mendekati sempurna, menunjukkan peserta dapat fokus menerima materi dengan maksimal.

\subsection{Pembahasan}

Menurut United Development Economic and Social Affairs (UNDESA, 2010), Indonesia termasuk negara ke-37 dengan persentase pernikahan usia muda yang tinggi dan merupakan tertinggi kedua di ASEAN setelah Kamboja. Pada tahun 2010, terdapat 158 negara dengan usia legal minimal perempuan menikah adalah 18 tahun ke atas, namun di Indonesia batas usia minimal untuk perempuan adalah 16 tahun. Pernikahan usia muda berisiko karena belum cukupnya kesiapan dari aspek kesehatan, mental emosional, pendidikaan, sosial ekonomi, dan reproduksi (Hull, 2012). Badan Pusat Statistik (BPS) bekerja sama dengan Badan Dunia untuk Anak (UNICEF) merilis laporan analisis data perkawinan usia anak pertama kalinya di Indonesia. Pada laporan tersebut, angka perkawinan usia anak atau di bawah 18 tahun di Indonesia tinggi, sekitar 23 persen. Badan Pusat Statistik (BPS) juga mencatat bahwa angka kejadian atau prevalensi pernikahan anak lebih banyak terjadi di pedesaan dengan angka 27,11 persen dibandingkan di perkotaan yang berada pada 17,09 persen (BPS, 2016).

Pertumbuhan dan perkembangan remaja tidak lepas dari pengaruh bawaan yang berkaitan dengan sifat-sifat atau karakteristik genetika yang diturunkan oleh orang tua, serta pengaruh lingkungan yang berkaitan dengan keluarga, sekolah, teman bermain, atau lingkungan masyarakat umum. Pemahaman tentang dinamika perkembangan remaja amat diperlukan bagi orang tua maupun pendidik yang banyak berhubungan dengan mereka. Kasus-kasus pelecehan seksual, perkosaan, aborsi, tawuran, narkoba, maupun kriminalitas yang melibatkan remaja menjadi berita sering muncul dimedia massa yang ada dimasyarakat. Usia remaja adalah usia yang ideal untuk proses belajar serta mengeksplorasi dan mengembangkan diri, hal ini menjadi sia-sia karena terjadi penyimpangan-penyimpangan atau gangguan-gangguan perilaku yang harus mereka alami. (Jones, 2011).

Secara demografis kelurahan Tebing Tinggi Okura merupakan wilayah pinggiran kota yang sebagian besar adalah daerah kebun sawit dan karet. SMPN 28 berada disekitar kebun sawit tersebut. Kegiatan pengabmas tentang Pembentukkan PIK-KRR terinspirasi dari hasil penelitian yang dilakukan oleh salah satu mahasiswa DIV Kebidanan dengan judul "Faktor Penyebab dan Dampak Pernikahan Dini di Kecamatan Kandis Kabupaten Siak Tahun 2018". Hasil penelitian tersebut mengungkapkan bahwa salah satu faktor penyebab pernikahan usia muda adalah kehamilan diluar nikah, yang selanjutnya berdampak pada peningkatan siswa yang putus sekolah. Lingkungan demografis wilayah yang serupa dengan kecamatan Kandis, menjadikan okura daerah yang rawan terhadap pergaulan bebas dan perilaku remaja menyimpang lainnya. Hal ini terbukti dengan adanya kasus drop out siswa/siswi SMPN 28 yang disebabkan oleh kehamilan diusia muda dan kenakalan remaja. Solusi fenomena tersebut di bahas dalam hasil laporan penelitian, dengan meningkatkan pengetahuan dan pemahaman remaja berkaitan dengan kesehatan reproduksi. Pembentukkan PIK-R Action menjadi solusi yang patut dipertimbangkan untuk segera diwujudkan, yang selanjutnya dilaksanakan dengan maksimal dengan dukungan seluruh pihak. Bantuan pihak sekolah dan orang tua berperan besar untuk mengatasi masalah di atas, mengingat permasalahan remaja menjadi point utama yang urgen harus diatasi.

Sudah saatnya masyarakat bersama orang tua, pendidik maupun profesional menyatukan langkah untuk memahami, mengelola serta mengajak remaja mengembangkan diri secara positif dan konstruktif, sehingga di masa mendatang dapat tumbuh menjadi generasi muda yang dewasa, matang dan berkualitas. Perlu usaha-usaha yang intensif dan integratif 
dalam memaknai perilaku remaja, tidak saja yang ditampilkan, tetapi juga makna-makna yang seringkali tersembunyi dibalik penampilan mereka. Urgensi dalam memahami dinamika perkembangan remaja sesungguhnya merupakan salah satu bentuk perhatian dan kasih sayang yang wajar dari orang tua maupun masyarakat terhadap mereka, sehingga remaja dapat merasakan adanya kepedulian keluarga dan lingkungan terhadap keberadaan mereka. Manfaat lain yang dapat diperoleh adalah mengenal dan mengetahui potensi remaja, sehingga orang tua dapat menyalurkan secara tepat minat dan bakat mereka, serta mengantisipasi dan mencegah adanya gejala-gejala gangguan psikososial yang mungkin terjadi.

Masyarakat dapat memaknai perilaku remaja dengan cara mengenali dan memahami karakteristik atau ciri khas yang umum dimiliki oleh mereka. Remaja memiliki karakteristik yang tampak menonjol dalam perilaku kesehariannya, seperti: perkembangan usia kronologis berkisar antara 12-18 tahun, lebih banyak menghabiskan waktu bersama teman sebaya, keinginan untuk mandiri, kemampuan untuk memiliki dan memilih banyak rujukan (identifikasi), keinginan berpartisipasi dalam aktivitas-aktivitas kelompok, kurang membutuhkan (menolak) supervisi dari orang tua, cenderung bebas dalam mengekspresikan dan menampilkan diri, membutuhkan penerimaan sosial (masyarakat), serta saling berbagi dengan teman sebaya mengenai keyakinan dan minat sosial. Oleh karena itu organisasi PIK-R Action dapat menjadi wadah berkumpulnya remaja, untuk membincangkan masa depan yang terencana. Hadirnya kader sebagai konselor atau pendidik sebaya dapat menjadi jembatan penyaluran informasi berkaitan dengan usaha-usaha menjadi remaja yang sehat secara fisik mental.

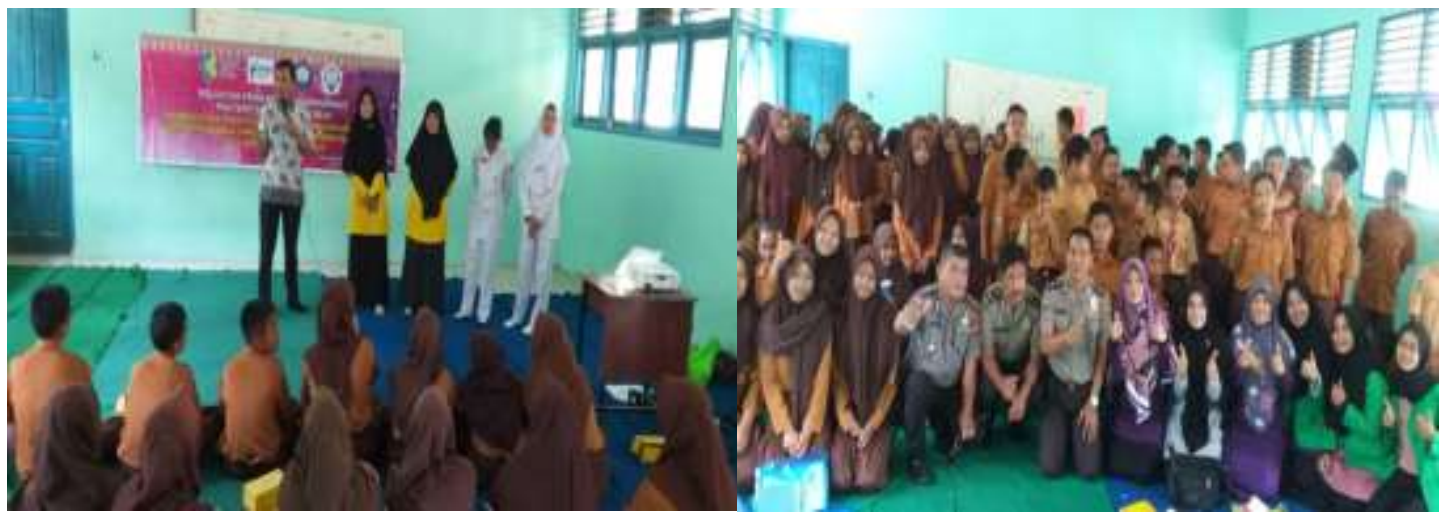

Gambar 2. Pembekalan Materi oleh tim dan Polda Riau
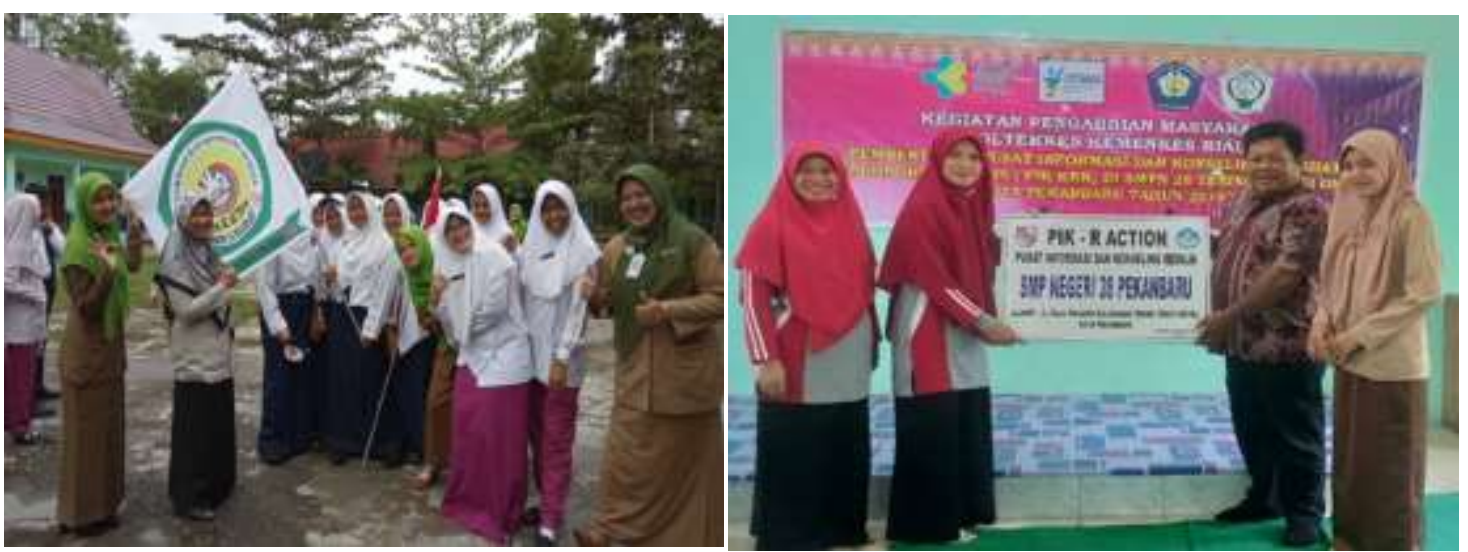

Gambar 3. Pelantikan PIK-R Action 


\section{KESIMPULAN}

Berikut kesimpulan dari kegiatan pengabdian ini :

1. Kegiatan sosialisasi dan pembekalan materi sudah dilakukan pada bulan Juni-Juli 2019 bertempat di ruang kelas SMPN 28 yang dengan jumlah peserta 18 orang siswa/siswi. Hasil pretest dan posttest, mengalami peningkatan pengetahuan peserta, yaitu dari ratarata nilai 75 menjadi rata-rata 96.

2. Praktik menjadi konselor atau pendidik sebaya oleh kader PIK-R Action dilakukan pada pertemuan terakhir kegiatan pengabmas. Demontrasi langsung dilakukan pada kelompok-kelompok kecil yang telah ditentukan, hasilnya sangat memuaskan, konselor sebaya cukup terampil dalam memberikan materi PIK-R.

Saran

Disarankan kepada kader PIK-R dapat rutin mengadakan kegiatan konseling pada teman sebaya, sesuai dengan modul pelatihan. Penyuluhan berkelompok dapat dijadikan agenda setiap bulannnya, dengan materi yang berbeda, terutama tentang kesehatan reproduksi remaja, pendewasaan usia perkawinan, HIV/AIDS dan dampak penyalahgunaan NAPZA. Dan pihak SMPN 28 dapat terus mendukung dan memberikan pembinaan agar kader menjadi lebih terampil dan termotivasi melakukan konseling pada teman sebaya.

\section{UCAPAN TERIMA KASIH}

Penulis mengucapkan terima kasih kepada Poltekkes Kemenkes Riau yang telah memberi dukungan dana sehingga terlaksananya kegiatan pengabdian ini. Terima kasih juga pada Kepala SMPN 28 Tebing Tinggi Okura Kota Pekanbaru beserta staf, yang telah memfasilitasi tim dalam melakukan kegiatan ini.

\section{DAFTAR PUSTAKA}

BKKBN (2007). Pedoman KIE Kesehatan Reproduksi. Jakarta.

BKKBN (2012). Pedoman Pengelolaan Pusat Informasi dan Konseling Kesehatan Reproduksi Remaja (PIK-KRR).Jakarta.

BKKBN (2013). Mengenal Sekilas Genre, PIK-R/M, BKR. Bandung

BKKBN (2017). Promosi dan Konseling Kesehatan Reproduksi Bagi Kelompok Kegiatan PIKRemaja. Direktorat Kesehatan Reproduksi BKKBN.

Fadlyana, Eddy. Larasaty, Shinta (2009). Pernikahan Usia Dini dan Permasalahannya. Jurnal Sari Pediatri, Vol II.No.2 Agustus 2009. FK UNPAD, Bandung.

Hull.T.H. (2012). "Indonesia's Demographic Mosaic". Population Dynamics in Muslim Countries. Springea Berlin Heidelberg.

Isa, Muhammad (2017). Tren Usia Perkawinan Pertama di Indonesia. Brief Notes Lembaga Demografi FEB UI. Jakarta.

Jones.G.W \& Gubhaju.B (2011). "Regional Differences in Marriage Pattern in Indonesia in the Twenty-Firts Century". Changging Marriage Partterns in Southeas Asia. 